Bulletin of Pharmaceutical Sciences
Assiut University
Website: http://bpsa.journals.ekb.eg/
e-mail: bullpharm@aun.edu.eg

\title{
DETECTION OF PROTEUS SPECIES IN DIABETIC WOUNDS AND THEIR ANTIBIOTIC RESISTANCE PROFILE ANALYSIS
}

\author{
Amany G. Thabit, Ehsan Abd El-Sabour, Amany M. Adawy Nafie, Mohamed A. El-Mokhtar \\ and Yousra E. Biomy*
}

Department of Medical Microbiology and Immunology, Faculty of Medicine, Assiut University, Assiut, Egypt

\begin{abstract}
This work was carried out to determine the incidence of Proteus species infection in patients had diabetic foot wounds admitted to Vascular Surgery Department at Assiut University Hospitals. Proteus isolates were the most isolated organism (37.73\%) followed by Klebsiella spp. (22.64\%), then Pseudomonas spp. (20.75\%) and E. coli (18.87\%). Proteus mirabils was the most isolated species represented (78\%) followed by Proteus vulgaris (13\%) then Proteus penneri (9\%).

The antimicrobial susceptibility patterns of the isolated Proteus spp. were determined using agar disk diffusion method. The highest sensitivity was to ertapenem 76 isolates (76\%). The antibiotic sensitivity then decrease in descending manner to be amikacin (65\%) > meropenem $(54 \%)>$ imipenem $(52 \%)>$ cefipime $(49 \%)$, while the highest resistance rates were to amoxicillin-clavulanic acid 75 isolates $(75 \%)>$ co-trimoxazole $(73 \%)>$ cefoxitin $(63 \%)>$ ciprofloxacin (49\%). Plasmid DNA profile analysis of 10 MDR Proteus mirabilis that were common resistant to ceftriaxone was studied. Plasmid bands of six resistant Proteus mirabilis isolates were shown at $800 \mathrm{bp}$ while the others at $700 \mathrm{bp}$.

Plasmid curing was done by EtBr and SDS. Results of plasmid curing using ethidium bromide sublethal concentration of EtBr $1.25 \%$ showed that 7 cured cells become sensitive to ceftriaxone $(30 \mu \mathrm{g})$, while 3 non cured cell still resistant to ceftriaxone. Plasmid curing using SDS sublethal concentration of SDS 1.2\% cured only one of ten Proteus mirabilis which become sensitive to ceftriaxone and lost its band at 800bp, the other Proteus mirabilis not cured by SDS.
\end{abstract}

\section{INTRODUCTION}

Diabetic wound lesions are a major medical, social and economic problem and are the leading cause of hospitalization for patients with diabetes ${ }^{1}$.

It is one of the world's major important health complications as well as a significant factor in the cost of inpatient treatment, loss of lives, disability and a reduction in life expectancy ${ }^{2}$.

Diabetic wounds/or foot ulcers and infections can lead to amputation of the foot or leg and one out 15 diabetic patients requires a limb amputation during their lifetime ${ }^{3}$. According to Ravisekhar et al. ${ }^{1}$ several enterobacteria and Gram positive bacteria have been found to be associated with diabetic foot ulcers; therefore this should be a matter of great concern for those who treat and rehabilitate diabetic wounds.

Foot infections are the most common complications of diabetic foot and plays a main role in the development of moist gangrene ${ }^{4}$, Pseudomonas spp., Enterococcus spp. \& Proteus spp. carry a special role and are responsible for continuing and extensive tissue destruction with the poor blood circulation of the foot ${ }^{5}$. Proteus colonizing the intestinal tract and wounds vary in their carriage of genes encoding antibiotic resistance ${ }^{6}$.

Received in 26/2/2019 \& Accepted in 15/12/2019 
The routine use of antimicrobial agents in both human and veterinary medicine has resulted in widespread antibiotic resistance and the development of antibiotic resistance genes especially within and between the gramnegative bacteria ${ }^{7}$. With the presence of antibiotics selective pressure, these resistant Proteus species tend to persist, enabling the organism to cause extra infections such as septicemia ${ }^{8}$.

The increasing association of multidrug resistant organisms (MDROs) with diabetic foot ulcers increases the risk of limb amputation". Infection with MDROs is also responsible for the increased duration of hospitalization, cost of management, morbidity and mortality of the diabetic patients ${ }^{10}$. Plasmids serve a central role in mechanisms of bacterial antibiotic resistance ${ }^{11}$. Plasmid sometime can be eliminated or lost from host cells by various treatments. This process termed curing. Curing may occur spontaneously or induced. It is greatly increased by application of some physical and chemical factors such as acridine dye, sodium dodecyl sulfate (SDS) and ethidium bromide dye. Using of heavy metals, ultraviolet, ionizing radiation or growth at temperature above the optimum may also result in elimination of the plasmid ${ }^{12}$.

Some commonly used curing treatments are acridine mutagens, ion and ionizing radiation, thyme starvation, antibiotics and growth above optimum temperature, $\mathrm{pH}$ or extreme environmental conditions ${ }^{13}$.

Appropriate selection of antibiotics based on the antibiogram of the isolates from the lesions is most critical for the proper management of these infections. Nevertheless, the initial empirical therapy is often decided based on the knowledge of the susceptibility profile of the prevalent microbial flora recovered from the previous cases.

The magic bullets, the miraculous drugs, antibiotics can be used to heal the diabetic wounds and thus the complications, which are a threat to all diabetic patients and thus can be minimized to a great extent ${ }^{14}$.

\section{METHODS}

\section{Isolation}

This study included 251 patients admitted to Vascular Surgery Department at Assiut
University Hospitals. They were of different ages (30-82 years) and sex (141 males and 110 females). Samples were collected from patients with diabetes mellitus (type1 and type 2) had wound foot infection. Two hundred and fifty one different clinical samples were collected under aseptic condition. These samples included debridement material and drained pus obtained during surgery from lesions.

\section{Isolation of gram negative bacteria including Proteus spp.}

The specimens were collected with sterile swabs and inoculated on blood agar and MacConkey agar at $37^{\circ} \mathrm{C}$ for $24 \mathrm{~h}$. Identification of Proteus isolates and other Gram negative bacteria by conventional biochemical tests such as catalase test, oxidase test, nitrate reduction test, IMVC test, urease Christensen's test, triple sugar iron test (TSI), motility indole ornithine medium (MIO), maltose fermentation test and citrate test ${ }^{15}$.

\section{Antibiotic susceptibility test}

Antimicrobial susceptibility testing of Proteus isolates by the Kirby-Bauer disc diffusion method according to Clinical and Laboratory Standards Institute ${ }^{16}$. The antimicrobial agents tested were Amoxicillinclavulanic acid $(20 / 10 \mu \mathrm{g})$, Piperacillin (100 $\mu \mathrm{g})$, Imipenem $(10 \mu \mathrm{g})$, Meropenom $(10 \mu \mathrm{g})$, Ertapenem(10 $\mu \mathrm{g})$, Cefoxitin (30 $\mu \mathrm{g})$, Ceftriaxone $(30 \mu \mathrm{g})$, Cefipime $(30 \mu \mathrm{g})$, Ciprofloxacin $(5 \mu \mathrm{g})$, Levofloxacin $(5 \mu \mathrm{g})$, Amikacin $(30 \mu \mathrm{g})$,Co-triamoxazole $(1.25 / 23.75$ $\mu \mathrm{g})$. inoculated plates and incubated overnight. The zones of inhibition were measured and interpreted.

\section{Plasmid profile analysis}

Ten multidrug resistant Proteus isolates which were resistant to at least three antibiotics agents of 3 different groups including ceftriaxone as common agent were selected for plasmid analysis.

Extraction of plasmid DNA was done following rapid alkaline method ${ }^{17}$. DNA is separated by gel electrophoresis based on its molecular mass, the bands of sample is compared to the DNA ladder so can determine their approximate size. 


\section{Plasmid curing}

The methods described by Trevors ${ }^{18}$ and Iwalokun et al. ${ }^{19}$ were used in this study to cure plasmids using two different agents;

1- Sodium dodecyl sulphate (SDS) at final concentrations as follows: $(0.2,0.4,0.5$, $0.8,1,1.2,1.4,1.6,1.8$ and $2 \%)$.

2- Ethidium bromide at final concentrations as follows: $(0.75 \%, 1.25 \%$ and $1.5 \%)$.

The ten $P$. mirabilis isolates which their plasmid profile analysis previously determined were selected. After treatment of bacterial isolates with curing agent, colonies that still able to grow on nutrient agar were selected randomly and were replica plated on nutrient agar plates containing the antibiotic discs to which the wild isolate was resist. Plates then incubated at $37^{\circ} \mathrm{C}$ for $24 \mathrm{hrs}$ to test sensitivity to ceftriaxone after curing. Plasmid extraction of cured strains and agarose gel electrophoresis with $1 \%$ agarose was done again.

\section{RESULTS AND DISCUSSION}

In the present study, the majority of diabetic wound infection were caused by mixed infection of 2 organisms $(71.7 \%)$. The monomicrobial infection was $(28.3 \%)$. In consistent with this work Raja ${ }^{20}$ reported that $42 \%$ of patients developed mixed growth. Similarly, Llanes et $a .^{21}$, reported that $58.9 \%$ of cases were polymicrobial in nature. Other studies from Jamaica and France documented that the prevalence of polymicrobial infection could be as high as $80-87.2 \%{ }^{22}$. In this study, Proteus spp. was the most isolated organism $(37.73 \%)$ followed by Klebsiella spp. (22.64\%), Pseudomonas spp. (20.75\%) and E. coli $(18.87 \%)$. This was matching with the studies of Raja $^{20}$ and Oguachuba ${ }^{23}$ which showed that Proteus spp. was the commonest gram-negative etiological agent from wound infections. Also Ramakant et al. ${ }^{24}$, who studied the changing of microbiological profile of pathogenic bacteria isolated from DFU in, Lucknow, India over a period of 8 years; 1632 cultures were isolated from 434 patients with diabetic foot infections, showing that Gramnegative bacterial infection was increasing from $50.6 \%$ to $66 \%$ and the most common isolates were $P$. aeruginosa, E. coli and Proteus spp.
In this research out of 251 clinical specimens, Proteus isolates were 100 which comprising 78 Proteus mirabilis (78\%), 13 Proteus vulgaris (13\%) and 9 Proteus penneri (9\%) (Table 1). Mathew and Suchithra ${ }^{25}$ showed that the order of occurrence of gram negative isolates in diabetic wound ulcers was Proteus mirabilis (22.73\%) > Enterobacter aeruginosa $(18.18 \%)>$ Klebsiella pneumonia $(18.18 \%)>$ Pseudomonas aeruginosa $(13.64 \%)$ $>$ Salmonella typhi $(13.64 \%)>$ E.coli $(9.09 \%)$ $>$ Proteus vulgaris $(4.55 \%)$.

Although P. mirabilis was isolated more frequently than the other Proteus species in this study (78\%), however, it is lower than that claimed by Auwaerter ${ }^{26}(90 \%)$. Comparably to this research in Nigeria a total of 148 Proteus isolates comprising of 97 P. mirabilis and 51 Proteus vulgaris were isolated from diabetic wounds of diabetes patients attending Ahmadu Bello University Teaching Hospital Zaria, Kaduna State, Nigeria ${ }^{27}$.

In the present study the majority of Proteus infection in diabetic wounds were detected in the age group $>50-82$ years which accounted for $45 \%$ of the positive cases. The infection rate of patient aged $>40-50$ years was $32 \%$ followed by age group 30-40 years which was $23 \%$. There was significant difference of the rate of Proteus infection among different age groups.

Concerning gender, sixty five patients $(65 \%)$ were males while thirty five patients $(35 \%)$ were females. The greater percentage of males in this study may be either due to males selectively presenting to health services or due to that males being more exposed to foot trauma in the outdoors. This is comparable to another study where out of 107 patients with diabetic foot from surgical units, 70 were males and 37 were females patients and the age ranged from 17 to 66 years with mean age being 43 years $^{28}$.

In the present study the antimicrobial susceptibility patterns of the isolated Proteus spp. were done using agar disk diffusion method. The highest sensitivity rate was to ertapenem 76 isolates (76\%), amikacin (65\%), meropenem (54\%), imipenem (52\%) and cefipime $(49 \%)$ (Fig. 1). This partly coincide with study carried out by Makled and Alghamdi $^{29}$ which showed that aminoglycosides commonly used in treatment of 
Table 1: Identification of Proteus Spp.

\begin{tabular}{||l|c|c|c||}
\hline & Proteus mirabilis & Proteus vulgaris & Proteus penneri \\
\hline Indole production test & - ve & $\begin{array}{c}\text { + ve (red ring in alcoholic } \\
\text { layer) }\end{array}$ & -ve \\
\hline $\begin{array}{l}\text { Ornithine decarboxylase } \\
\text { test }\end{array}$ & + ve(purple color) & - ve (yellow color) & + ve \\
\hline Maltose fermentation test & - ve & - ve & yellow slant, yellow butt \\
\hline TSI tests & Red slant, black butt & yellow slant, black butt & citrate negative \\
\hline Citrate test & citrate positive & citrate negative & $9 \%$ \\
\hline No. of Proteus isolates $(\%)$ & $78 \%$ & $13 \%$ & \\
\hline
\end{tabular}

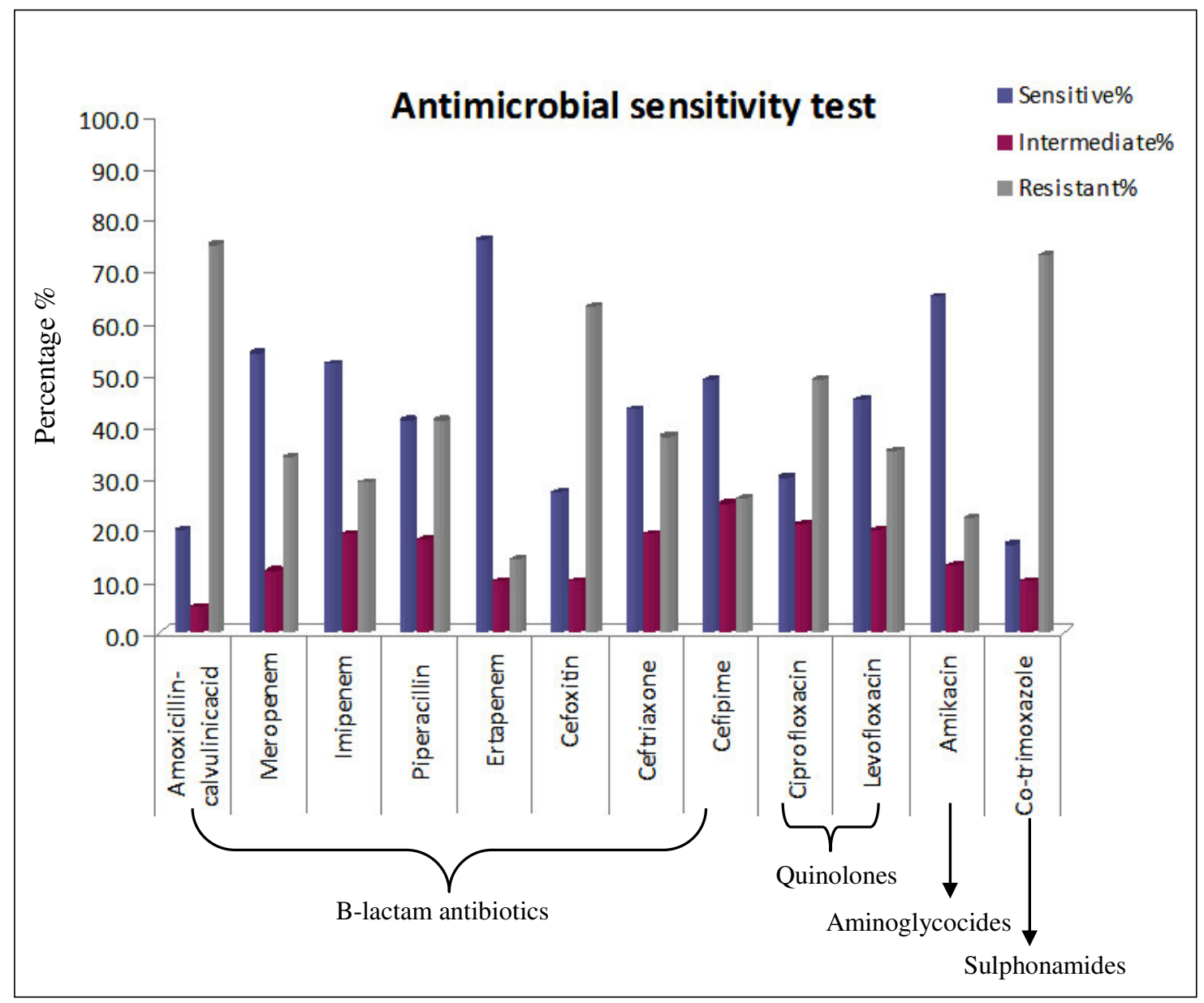

Fig. 1: The antibiotic sensitivity test of Proteus isolates. 
infections caused by $P$. mirabilis isolates are still effective. Also, the antimicrobial susceptibility testing carried out by ElTahawy ${ }^{30}$ showed that imipenem was the most effective agent against gram-negative organisms.

The highest resistance rates in this work were to amoxicillin - clavulanic acid 75 isolates $(75 \%)$, co-trimoxazole $(73 \%)$, cefoxitin (63\%) and ciprofloxacin (49\%). Resistance of $77-85 \%$ of Proteus spp. against ampicillin, cotrimoxazole, tetracycline, and chloramphenicol was reported by Feglo et al. $^{31}$ who added that the high level of $\beta$-lactamase production and multi-drug resistance of the isolates are indications of an increase in the resistance menace. In this study the resistance to ceftriaxone was $(38 \%)$, Similar results were reported by Jawad and Alramahy ${ }^{32}$ in which the resistant pattern of Proteus spp. to 3rd generation cephalosporins were to cefuroxime $(37.1 \%)$ and ceftriaxone $(33.8 \%)$.

Swenson Jana and Patel Jean ${ }^{33}$ showed that virtually all Proteus vulgaris and Proteus penneri strains are capable of producing inducible $\beta$-lactamases that will hydrolyze primary and extended-spectrum penicillin and cephalosporins. Proteus mirabilis which lacks intrinsic chromosomal $\beta$-lactamase genes is entirely dependent upon acquisition of different b-lactamase genes to express a $\beta$-lactamasemediated resistance phenotype.

In the present study plasmid profile of 10 multidrug resistant Proteus mirabilis resistant to at least three antibiotics of 3 different groups including ceftriaxone antibiotic as the common agent was done. Ceftriaxone was chosen because it is the empirical treatment in Assiut University Hospitals. Ceftriaxone has been effective in treating infections due to MDR enterobacteriaceae where the long half-life of the drug result in worthwhile convenience and cost benefits $^{34}$. It is a choice drug for surgical prophylaxis and treatment. It is on the WHO Model List of Essential Medicines (2016) as the most effective and safe medicinal needed in a health system ${ }^{35}$.

Plasmid DNA was obtained using alkaline lysis method ${ }^{17}$. It was found that all of the 10 multidrug resistant Proteus mirabilis had plasmid. The agarose gel electrophoresis for 6 of them showed bands at $800 \mathrm{bp}$ and the other four showed at $700 \mathrm{bp} .{ }^{27}$ mentioned that the plasmid band of Proteus isolates showed at range from $<0.45 \mathrm{~kb}$ to $>1.25 \mathrm{~kb}$ (Fig. $2 \&$ Table 2).

Table 2: Plasmid profile of ceftriaxone resistant Proteus mirabilis.

\begin{tabular}{|c|c|c|}
\hline Proteus species & Antibiotics resistance to antibiotic & Band bp \\
\hline $\begin{array}{l}\text { Plasmid profile of } 6 \text { resistant } \\
\text { Proteus mirabilis }\end{array}$ & $\begin{array}{l}\text { CRO, AMC, PRL, FOX, LEV, CIP } \\
\text { CRO, FEP, AK, LEV, FOX } \\
\text { CRO, AMC, LEV, CIP, FOX, MEM, FEP } \\
\text { CRO, AMC, FOX, AK, MEM } \\
\text { CRO, AMC, MEM, PRL, FEP } \\
\text { CRO, AMC, FOX, FEP, PRL, CIP }\end{array}$ & 800 \\
\hline $\begin{array}{l}\text { Plasmid profile of } 4 \text { resistant } \\
\text { Proteus mirabilis }\end{array}$ & $\begin{array}{l}\text { CRO, AMC, AK, PRL, FEP } \\
\text { CRO, AMC, AK, FOX, FEP } \\
\text { CRO, AMC, AK, MEM, CIP } \\
\text { CRO, AMC, FEP, FOX, PRL, CIP }\end{array}$ & 700 \\
\hline
\end{tabular}

CRO (Ceftriaxone), AMC (Amoxicillin-clavulanic acid), AK (Amikacin), PRL (piperacillin), FOX (Cefoxitin), FEP (Cefipime), CIP (Ciprofloxacin), MEM (Meropenem), LEV (Levofloxacin). 


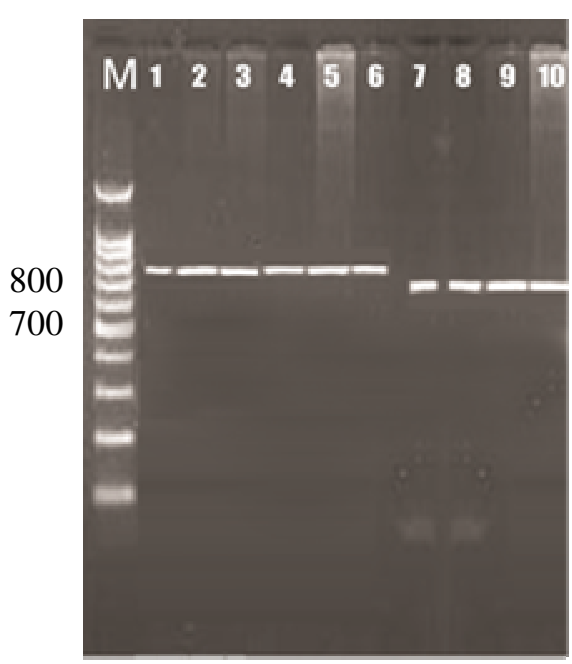

Fig. 2: Agarose gel electrophoresis of Plasmid DNA of Proteus mirabilis resistant to ceftriaxone. Lane M: DNA marker (100-1500) ladder, Lanes (1, 2, 3, 4, 5 and 6) show plasmid bands at 800 bp. Lanes (7, 8, 9 and 10) show plasmid bands at $700 \mathrm{bp}$.

In this work curing of plasmid was done by SDS and EtBr. 7 of Proteus mirabilis cured by EtBr lost their bands at either 800 bp or 700 bp became sensitive to ceftriaxone and the noncured strains still resistant (Fig. 3).

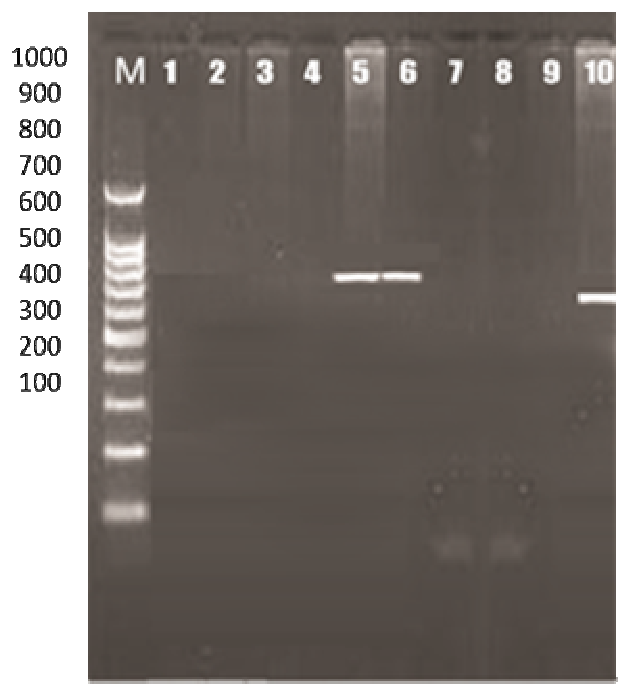

Fig. 3: Agarose gel electrophoresis of plasmid cured Proteus mirabilis by ethidium bromide. Cured Proteus mirabilis (1, 2, 3 and 4) lost plasmid bands at $800 \mathrm{bp}$. Cured Proteus mirabilis (7, 8 and 9) lost plasmid bands at 700 bp.
The same for the one strain cured with SDS became sensitive to ceftriaxone while the other 9 still resistant (Fig. 4). This proved that Proteus resistance to ceftriaxone was associated with plasmid had approximate sizes $700-800 \mathrm{bp}$. There is a possibility that these plasmids could carry other antibiotic resistance genes which didn't carried out in this study. Iwalokun et al. ${ }^{19}$ showed that plasmid curing with $1.25 \%$ ethidium bromide solution in some of Proteus Spp. confirmed strongly the involvement of chromosome and plasmid in antibiotic resistance. But, the present result revealed that the $\beta$-lactamase genes mostly located on plasmids for the analyzed strains. This result was in agreement with the finding of other investigators ${ }^{36}$ confirmed the location of antibiotic markers on R-plasmid by treating the cells with curing agents.

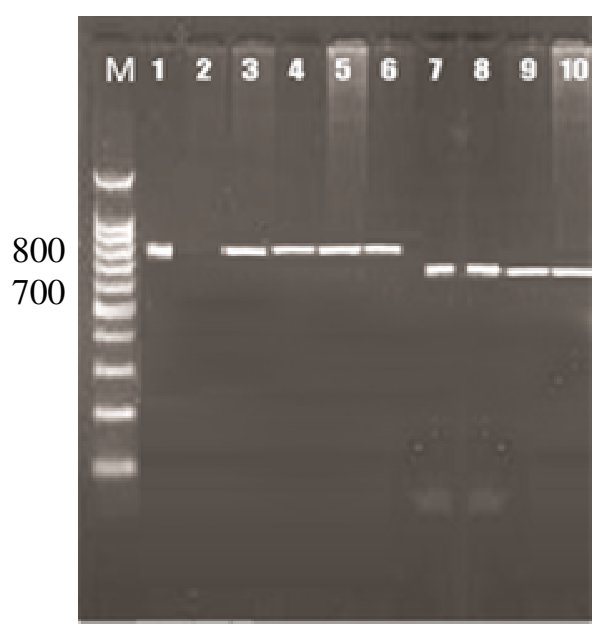

Fig. 4: Agarose gel electrophoresis of plasmid cured Proteus mirabilis by $10 \%$ SDS the cured cell lost its band (800 bp) on lane 2 .

The present study proved that EtBr with sublethal concentration at $1.25 \%$ was more effective as plasmid curing agent than SDS at $1.2 \%$ as it cured $7 / 10$ of plasmids while SDS cured only one. The $\mathrm{P}$ value between the two reagents was significant (0.022) (Fig. 5).

Antimicrobial resistance in Proteus is of great public health concern in the developing world. The accelerated emergence of antibiotic resistance among the prevalence pathogens is the most serious threat on the management of infectious diseases. 


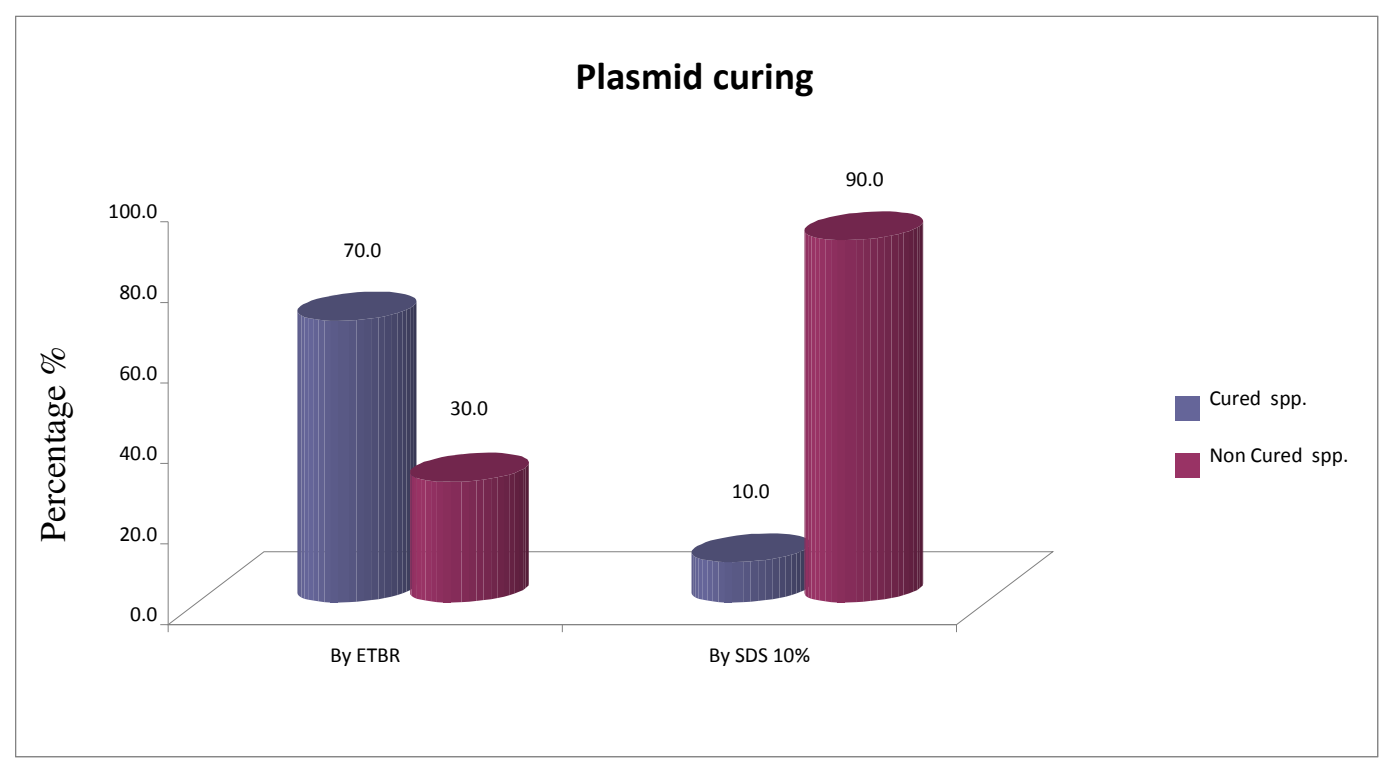

Fig. 5: Comparison between Ethidium bromide and SDS used for curing plasmid of Proteus mirabilis.

\section{Conclusion}

1- The study concluded that Proteus infection of DFI represented $39.84 \%$ in Vascular Surgery Department of Assiut University Hospitals during the period of this study. This is considered high rate of infection.

2- There is high resistance rate of Proteus to many antibiotics mainly amoxicillinclavulanic acid, co-trimoxazole, cefoxitin, and ciprofloxacin. So treatment of Proteus infection is problematic.

3- Ertapenem was the most effective antibiotics against Proteus. However, no single antibiotic was found to be an effective agent against all Proteus isolates.

4- Plasmid plays great role in Proteus resistance to ceftriaxone.

\section{REFERENCES}

1- G. Ravisekhar, et al., "Clinical microbiological study of diabetic foot ulcers in an Indian tertiary care hospital", Diabetic Care, 29 (8), 1727-1732 (2006).

2- P. Kumar and M. Clark, "Diabetes mellitus and other disorders of metabolism", Clinical Medicine, 2, 10691071 (2002).

3- C. Unachukwu, O. Obunge and O. Odia, "The bacteriology of diabetic foot ulcers in Port Harcourt, Nigeria", Nigerian Journal of Medicine: Journal of the National Association of Resident Doctors of Nigeria, 14 (2), 173-176 (2005).

4- J. Smith, J. Payne and T. Berue, "Diabetic Foot Lesions of Skin and Soft Tissue Infections of Surgical Importance", Chapter 14, The Surgeons Guide To Antimicrobial Chemotherapy, 2002, pp. 218-21.

5- D. G. Armstrong and L. A., Lavery, "Diabetic foot ulcers: Prevention, diagnosis and classification", American Family Physician, 57 (6), 1325-32, 13378 (1998).

6- A. U. Khan and A. Musharraf, "Plasmidmediated multiple antibiotic resistance in Proteus mirabilis isolated from patients with urinary tract infection", Medical Science Monitor: International Medical Journal of Experimental and Clinical Research, 10 (11), CR598-602 (2004).

7- Y. Eo and E. No, "Emerging quinolones resistant transfer genes among gramnegative bacteria, isolated from faeces of HIV/AIDS patients attending some Clinics and Hospitals in the City of Benin, Edo State, Nigeria", Online Journal of Health and Allied Sciences, 5 (3) (2006). 
8- H. M. a. K. J. Prescott Lm, "Microbiology", $4^{\text {th }}$ Edn. (2001).

9- R. Yoga, et al., "Bacteriology of diabetic foot lesions", The Medical Journal of Malaysia, 61, 14-16 (2006).

10- R. Gadepalli, et al., "A clinicomicrobiological study of diabetic foot ulcers in an Indian tertiary care hospital", Diabetes Care, 29 (8), 1727-1732 (2006).

11- T. J. Welch, et al., "Multiple antimicrobial resistance in plague: An emerging public health risk", PloS One, 2 (3), e309 (2007).

12- L. A. Omer, Z. F. A. Abdulrahman and R. H. Saeed, "Curing analysis of drug resistance plasmid in proteus mirabilis", Cihan University-Erbil Scientific Journal, Special Issue No. 2, 46-59, (2017). DOI: 10.24086/cuesj.si.2017.n2a5.

13- J.-C. Ogier, et al., "Identification of the bacterial microflora in dairy products by temporal temperature gradient gel electrophoresis", Appl. Environ. Microbiol., 68 (8), 3691-3701 (2002).

14- V. Rajalakshmi and V. Amsaveni, "Antibiotic susceptibility of bacterial pathogens isolated from diabetic patients", International Journal of Microbiological Research, 2 (3), 273-275 (2011).

15- R. G. Batchoun, S. F. Swedan and A. M. Shurman, "Extended spectrum", International Journal of Microbiology, 2009, (2009).

16- Clinical and Laboratory Standards Institute, "Performance Standards for Antimicrobial Susceptibility Testing", $26^{\text {th }}$ Edn., 2016, CLSI Wayne, PA.

17- H. Birnboim, "A Rapid Alkaline Extraction Method for The Isolation of Plasmid DNA, In Methods In Enzymology", Elsevier, 1983, pp. 243255.

18- J. Trevors, "Plasmid curing in bacteria", FEMS Microbiology Reviews, 1 (3-4), 149-157 (1986).

19- B. Iwalokun, et al., "Comparative biochemical and molecular evaluation of swarming of Proteus and effects of antiswarm agents", African Journal of Biotechnology, 3 (1), 99-104 (2004).

20- N. S. Raja, "Microbiology of diabetic foot infections in a teaching hospital in Malaysia: A retrospective study of 194 cases", Journal of Microbiology
Immunology and Infection, 40 (1), 39 (2007).

21- L. R. I. Llanes, A. C. Pena and R. Valera, "Clinical, microbiological profile and outcome of diabetic patients with foot ulcers admitted at the Quirino memorial medical center: January 2000 - May 2001", Phil. J. Microbiol. Infect. Dis., 30 (3), 101-107 (2001).

22- C. A. Loan, et al., "Severe Streptococcus agalactiae infection of the diabetic foot. A deleterious role of Streptococcus agalactiae?", Presse Medicale (Paris, France: 1983), 34 (7), 491-494 (2005).

23- H. Oguachuba, "Hospital infections in orthopaedic Traumatological department of the Jos Teaching Hospital", Niger. Med. J., 9, 99-101 (1985).

24- P. Ramakant, et al., "Changing microbiological profile of pathogenic bacteria in diabetic foot infections: Time for a rethink on which empirical therapy to choose?", Diabetologia, 54 (1), 58-64 (2011).

25- S. M. Mathew and T. Suchithra, "A Threatening Approach of Wound Microflora to Diabetic Ulcer Foot Management", Int. J. Curr. Microbiol. App. Sci., 3 (9), 640-6 (2014).

26- P. Auwaerter, "Antibiotic Guide", Johns Hopkins ABX (antibiotic) Guide, Baltimore, MD (2008).

27- S. Yah, et al., "Widespread plasmid resistance genes among Proteus species in diabetic wounds of patients in the Ahmadu Bello university teaching hospital (ABUTH) Zaria", African Journal of Biotechnology, 6 (15), (2007).

28- C. Anandi, et al., "Bacteriology of diabetic foot lesions", Indian Journal of Medical Microbiology, 22 (3), 175 (2004).

29- A. Makled and A. Alghamdi, "Surveillance of aminoglycosides resistance among Proteus mirabilis isolates from different units in Jeddah Hospitals, Saudi Arabia", Egyptian J. Med. Microbiol., 15 (2), 337-51 (2006).

30- A. El-Tahawy, "Bacteriology of diabetic foot", Saudi Medical Journal, 21 (4), 344-347 (2000).

31- P. K. Feglo, et al., "Occurrence, species distribution and antibiotic resistance of 
Proteus isolates: A case study at the Komfo Anokye Teaching Hospital (KATH) in Ghana", Int. J. Pharm. Sci. Res., 1 (9), 347-52 (2010).

32- N. Jawad and S. K. Alramahy, "Diagnosis of Proteus mirabilis using PCR technique and determining their sensitivity to some antibiotics", Al-Qadisiyah Journal of Pure Science, 22 (3), 692-703 (2017).

33- M. Swenson Jana and B. Patel Jean, "Special Phenotypic Methods for Detecting Antibacterial Resistance", Vol. 1. Murray Patrick R, Baron Ellen Jo, Jorgensen James H, Landry Marie Louise and Pfaller Michael A, Eds., 2007, ASM Press, Washington DC.
34- B. G. Katzung, S. B. Masters and A. J. Trevor, "Basic \& Clinical Pharmacology", McGrow-Hill, New York, $12^{\text {th }}$ Edn. (2012).

35- W. H. Organization, " $19^{\text {th }}$ WHO Model List of Essential Medicines", World Health Organization, Geneva, Switzerland (2015).

36- S. Dharmadhikari and S. Peshwe, "Molecular level studies on multiple antibiotic and serum resistance in UTI pathogens", Indian Journal of Biotechnology, 8 (1), 40-45, (2009). 
Bull. Pharm. Sci., Assiut University, Vol. 43, Issue 1, 2020, pp. 1-10.

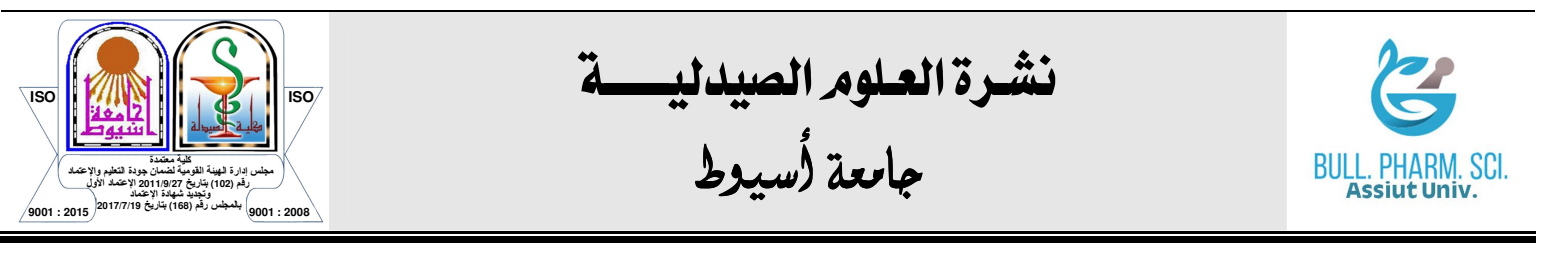

\section{الكثف عن فصائل البروتيس المعزولة من عدوي جروح القدم السكري ونمط

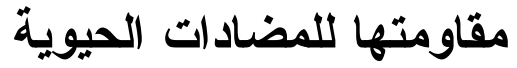

اماني جمال ثابت - إحسان عبد الصبور - أماني محمد عدوي نافع - محمد أحمد المختار - عزئ

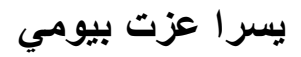

قسم الميكروبيولوجيا الطبية والمناعه ، كلية الطب ، جامعه أسيوط ، أسيوط ، مصر

تم هذا العمل لتحديد معدل الاصنابة بعز لات البروتيس في مرضي القدم السكري المترددين الي

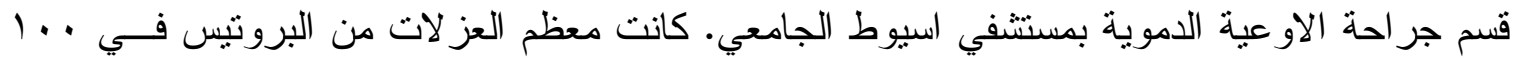

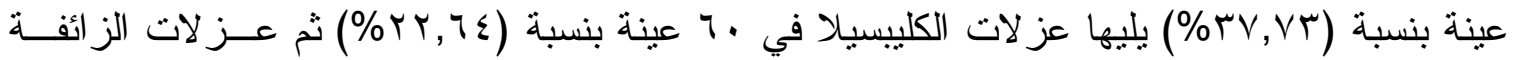

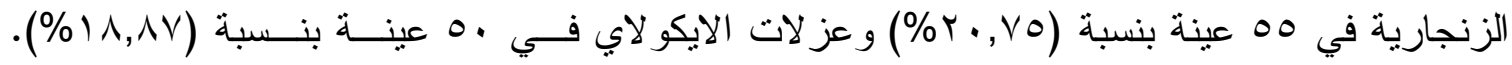

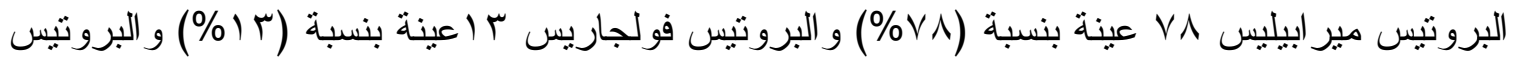

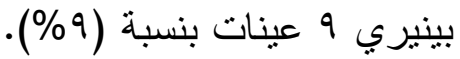

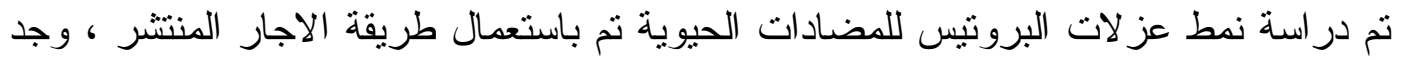

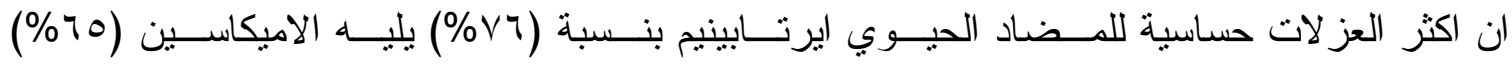

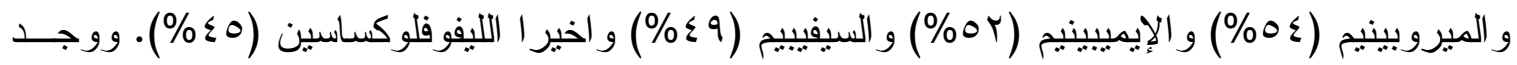

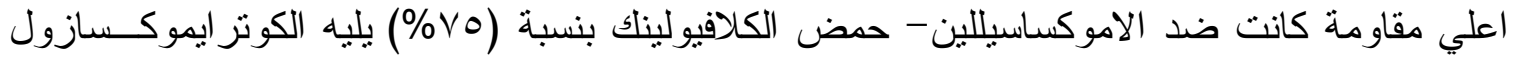

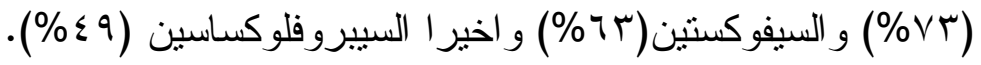

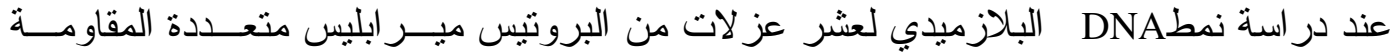

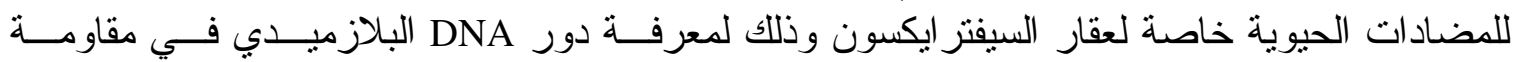

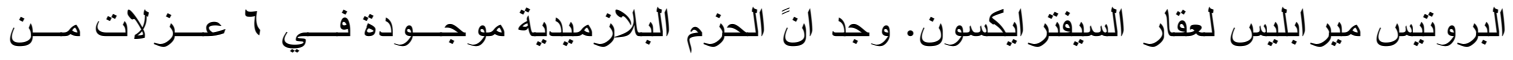

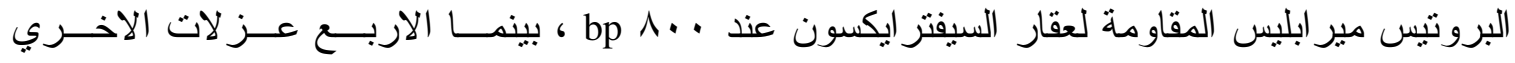

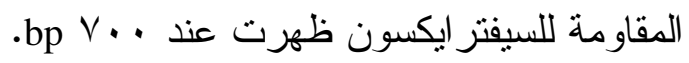

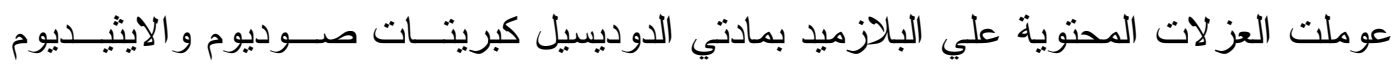

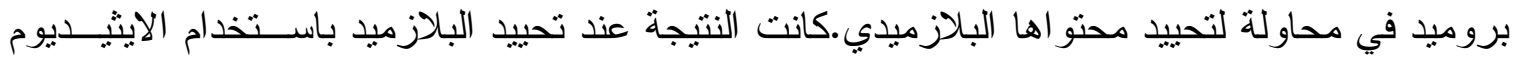

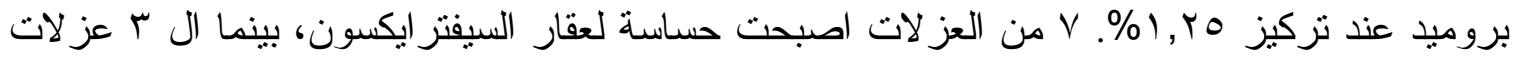

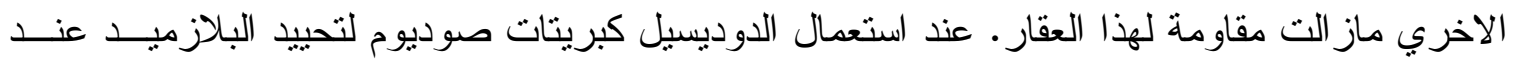
تركيز r, ا ب و وجد ان عزلة واحدة فقط من البروتيس مير ابليس اصبحت حساسة لعقار السيفتر ايكسون ، بينما باقي العز لات لم يتم تحييد محتو اها البلازميدي. 